\title{
Antibacterial organotin(IV) compounds, their synthesis and spectral characterization
}

\author{
Hidayat Hussain, ${ }^{\mathrm{a}, \mathrm{b}_{*}}$ Viqar Uddin Ahmad, ${ }^{\mathrm{b}}$ * Ivan Robert Green, ${ }^{\mathrm{c}}$ Karsten Krohn, ${ }^{\mathrm{a}}$ \\ Javid Hussain, ${ }^{d}$ and Amin Badshah ${ }^{e}$ \\ ${ }^{a}$ Department of Chemistry, University of Paderborn, Warburger Straße 100, 33098 Paderborn, \\ Germany \\ ${ }^{b}$ H.E.J. Research Institute of Chemistry, International Center for Chemical Sciences, University \\ of Karachi, Karachi 75270, Pakistan \\ ${ }^{c}$ Department of Chemistry, University of the Western Cape, P/Bag X17, Bellville,7530,_South \\ Africa \\ ${ }^{d}$ Department of Chemistry, Kohat University of Science and Technology, Kohat NWFP, Pakistan \\ ${ }^{e}$ Department of Chemistry, Quaid-e-Azam University, Islamabad, Pakistan \\ E-mail:hussain@mail.upb.de
}

\begin{abstract}
A series of of di- and triorganotin(IV) complexes of monoisopropyl and monomethyl maleate and monoisopropyl and triphenlymethyl glutarate have been synthesized and characterized by ${ }^{1} \mathrm{H}-{ }^{13} \mathrm{C}-{ }^{119} \mathrm{Sn}-\mathrm{NMR}$, UV, IR and Mass spectrometry. The spectroscopic investigation demonstrated that the carboxylate group acts as a bidentate ligand in diorganotin(IV) and as a monodentate ligand in triorganotin(IV) compounds. Biological evaluation against various microorganisms indicate that the diorganotin(IV) complexes are slightly less reactive than triorganotin(IV) complexes.
\end{abstract}

Keywords: Organotin(IV) carboxylates, spectroscopic studies, biological activity

\section{Introduction}

There have been several reports dealing with the impact of organotin chemistry in the biosphere. ${ }^{1,2}$ Organotin compounds show a large spectrum of biological activity but are mainly used commercially as industrial and agricultural biocides because of their antifungal properties. ${ }^{3}$ On the one hand some organotins are currently being investigated for antitumur activity ${ }^{4}$ while on the other hand some $\mathrm{R}_{3} \mathrm{SnL}$ derivatives ( $\mathrm{L}=$ monodentate or bidentate ligand) are highly toxic, $^{5-7}$ and additionally diorganotin(IV) derivatives like diethyltin(IV) and dibutyltin(IV) carboxylates are known antitumor agents. 8,9 


\section{Results and Discussion}

Different carboxylate ligands were prepared by treating maleic anhydride and glutaric anhydride with different alcohols. Two series of complexes i.e diorganotin(IV) (1-5) and triorganotin(IV) $(6,7)$ (Scheme 1; Figure 1) were subsequently prepared by reactions of monoester ligand (HL) and different organotin halides in 1:1 and 2:1 (ligand : metal) molar ratios and is illustrated in Scheme 1. The reactions of dibutyltin(IV) oxide with carboxylate ligands in a toluene-ethanol $(3: 1, \mathrm{v} / \mathrm{v})$ mixture afforded the complexes in a 1:2 molar ratio with the azeotropical removal of water. All the complexes are almost soluble in every organic solvent at room temperature.

$$
\begin{aligned}
& \mathrm{R}_{2} \mathrm{SnC}_{2}+2 \mathrm{HL}+2 \mathrm{Et}_{3} \mathrm{~N} \longrightarrow \mathrm{R}_{2} \mathrm{SnL}_{2}+2 \mathrm{Et}_{3} \mathrm{~N} . \mathrm{HCl} \\
& \mathrm{R}=\text { methyl and pheny } \\
& \mathrm{HL}=\text { monoisopropyl and monomethyl maleate, monoisopropyl glutarate } \\
& n-\mathrm{Bu}_{2} \mathrm{SnO}+2 \mathrm{HL} \longrightarrow n-\mathrm{Bu}_{2} \mathrm{SnL}_{2}+\mathrm{H}_{2} \mathrm{O} \\
& \mathrm{HL}=\text { monoisopropyl maleate, monoisopropyl glutarate } \\
& \mathrm{C}_{6} \mathrm{H}_{5} \mathrm{SnCl}_{3}+3 \mathrm{LHEt}_{3} \mathrm{~N} \longrightarrow \mathrm{C}_{6} \mathrm{H}_{5} \mathrm{SnL}_{3}+3 \mathrm{Et}_{3} \mathrm{~N} . \mathrm{HCl} \\
& \mathrm{HL}=\text { monoisopropyl and triphenymethyl glutarate }^{\longrightarrow}
\end{aligned}
$$

\section{Scheme 1}

\section{Electronic spectra}

The spectra of the ligands and their complexes were recorded in absolute ethanol. The various bands observed were assigned to interligand and charge transfer or $n \rightarrow \pi^{*}$ transitions according to their energies and intensities. It was found that the electronic spectra of these complexes exhibit very intense bands in the range of $200-210 \mathrm{~nm}$, which may be due to the $n \rightarrow \pi^{*}$ transition of the (COO) chromophore. ${ }^{10}$ Furthermore, there is a sharp band observed in the 255$270 \mathrm{~nm}$ region in the spectra of the complexes, which is ascribed to the charge-transfer band since it is known that metal/metalloids are capable of forming $\mathrm{d} \pi$-p $\pi$ bands with ligands containing nitrogen or oxygen as donor atoms. ${ }^{10}$ The tin atom has vacant $5 \mathrm{~d}$ orbitals and hence $\mathrm{L} \rightarrow \mathrm{M}$ electronic orbital overlap can take place by the acceptance of a pair of electrons from an oxygen donor atom of the ligand. ${ }^{10}$ 


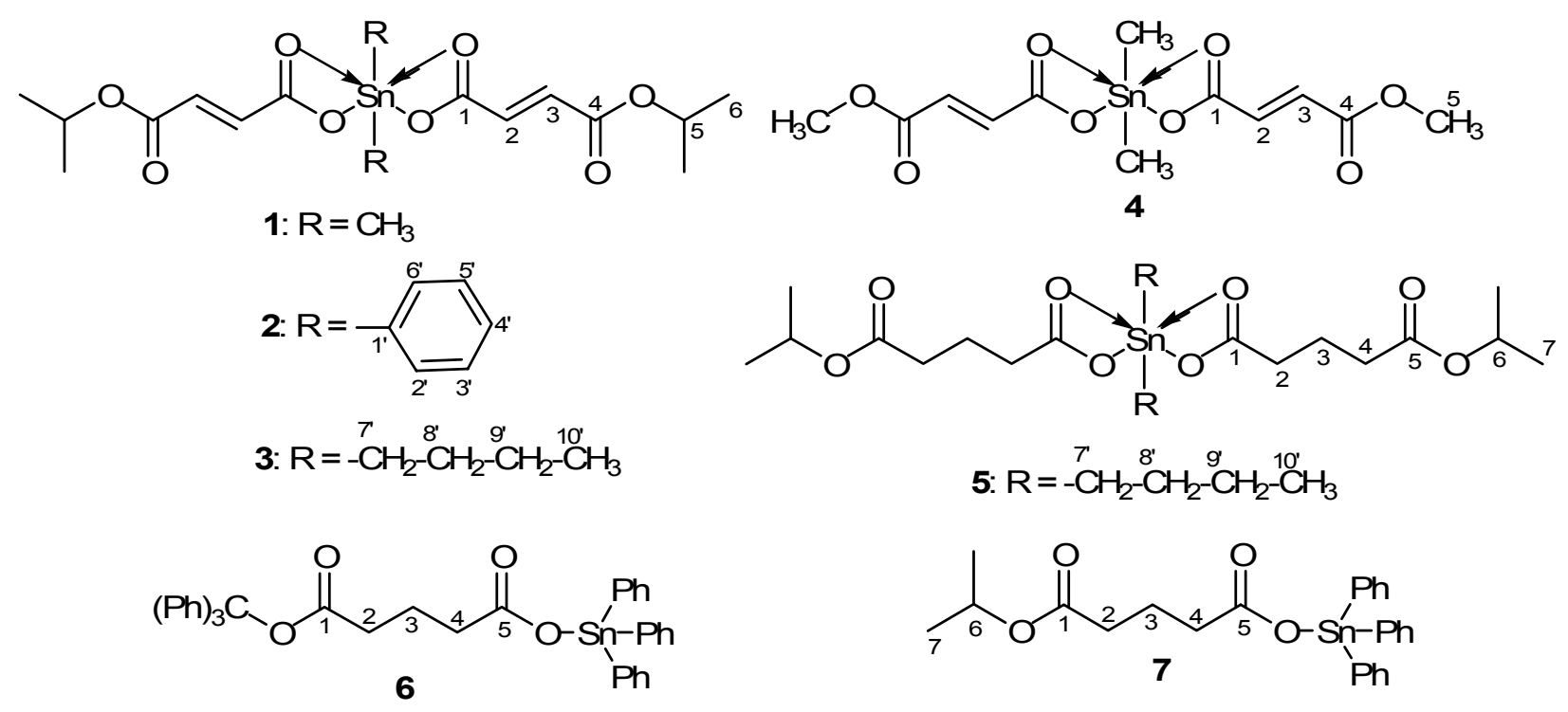

Figure 1. Proposed structures of di- and triorganotin(IV) complexes (1-7).

\section{Infrared spectroscopy}

The IR spectra of these compounds have been recorded in the range of $400-4000 \mathrm{~cm}^{-1}$. Tentative assignments have been made on the basis of earlier publications and the important data are listed in Table 1. The absorptions of interest in the spectra of the complexes are $v(\mathrm{COO}), v(\mathrm{Sn}-\mathrm{C})$ and $v(\mathrm{Sn}-\mathrm{O})$. The absence of the $v(\mathrm{OH})$ in all the organotin (IV) compounds in the $2500-3000 \mathrm{~cm}^{-1}$ region, and the presence of $v(\mathrm{Sn}-\mathrm{O})$ in the $450-475 \mathrm{~cm}^{-1}$ range $^{11}$ indicates deprotonation of the carboxylic acid group and consequent coordination of the carboxylate group with the tin metal as expected. The vacant $5 \mathrm{~d}$ orbital of tin atoms tends toward high coordination with ligands containing lone pairs of electrons.

The IR stretching frequencies of the carboxylate groups are very important for determining their structures viz., when there are interactions between the carbonyl oxygen atoms of the carboxylate groups and the tin atom, the asymmetric absorption vibration frequencies $v_{\text {asym }}$ $\left(\mathrm{CO}_{2}\right)$ of the carboxylate groups decrease and the symmetric absorption frequencies $v_{\mathrm{sym}}\left(\mathrm{CO}_{2}\right)$ increase. Their difference viz., $v \Delta\left(\mathrm{CO}_{2}\right)$, therefore decreases. ${ }^{11}$ In the IR spectra of the title compounds the carboxylate bands are observed in the characteristic regions for $v_{\text {asym }}\left(\mathrm{CO}_{2}\right)$ between 1640 and $1575 \mathrm{~cm}^{-1}$ and for $v_{\text {sym }}\left(\mathrm{CO}_{2}\right)$ between 1420 and $1310 \mathrm{~cm}^{-1}$ (Table 1).

In the triorganotin (IV) derivatives, $\mathbf{6}$ and $\mathbf{7}$, the differences $\left[v \Delta\left(\mathrm{CO}_{2}\right)\right]$ between $v_{\text {asym }}\left(\mathrm{CO}_{2}\right)$ and $v_{\text {sym }}\left(\mathrm{CO}_{2}\right)$ are more than $200 \mathrm{~cm}^{-1}$ indicating the covalent nature of the metal-oxygen bond. ${ }^{12}$ Ionic bonding and also bridging or chelation, therefore, can be excluded, and unidentate coordination of the carboxylic groups bonding to the metal must therefore be assumed. ${ }^{11}$ In the diorganotin (IV) derivatives 1-5, the frequencies $v_{\mathrm{sym}}\left(\mathrm{CO}_{2}\right)$ are shifted to higher wave numbers compared to those of the free acids. 
Table 1. Infrared frequencies $\left(\mathrm{cm}^{-1}\right)$ of organotin derivatives

\begin{tabular}{llllll}
\hline Compd. & $v a s y m\left(\mathrm{CO}_{2}\right)$ & $v$ sym $\left(\mathrm{CO}_{2}\right)$ & $\Delta v\left(\mathrm{CO}_{2}\right)$ & $v(\mathrm{Sn}-\mathrm{O})$ & $v(\mathrm{Sn}-\mathrm{C})$ \\
\hline $\mathbf{1}$ & $1590 \mathrm{~m}$ & $1415 \mathrm{~m}$ & 175 & $455 \mathrm{~m}$ & $530 \mathrm{~s}$ \\
$\mathbf{2}$ & $1585 \mathrm{~s}$ & $1405 \mathrm{~m}$ & 180 & $465 \mathrm{~m}$ & $525 \mathrm{~m}$ \\
$\mathbf{3}$ & $1583 \mathrm{~s}$ & $1415 \mathrm{~s}$ & 168 & $453 \mathrm{~s}$ & $540 \mathrm{w}$ \\
$\mathbf{4}$ & $1570 \mathrm{~m}$ & $1405 \mathrm{~s}$ & 165 & $457 \mathrm{~s}$ & $530 \mathrm{~m}$ \\
$\mathbf{5}$ & $1580 \mathrm{~s}$ & $1407 \mathrm{~m}$ & 173 & $455 \mathrm{~m}$ & $530 \mathrm{~s}$ \\
$\mathbf{6}$ & $1615 \mathrm{~s}$ & $1345 \mathrm{~s}$ & 270 & $457 \mathrm{~m}$ & $518 \mathrm{~s}$ \\
$\mathbf{7}$ & $1600 \mathrm{~s}$ & $1350 \mathrm{~m}$ & 250 & $460 \mathrm{~m}$ & $535 \mathrm{w}$ \\
\hline
\end{tabular}

s: Strong; m: Medium; w: Weak.

The frequency diffrences viz., $v \Delta\left(\mathrm{CO}_{2}\right)$, in the diorganotin derivatives, $\mathbf{1 - 5}$ is smaller than the corresponding $v \Delta\left(\mathrm{CO}_{2}\right)$ values of the triorganotin derivatives and this may attributed to steric crowding around the tin atom. Thus, for diorganotin compounds the $v \Delta\left(\mathrm{CO}_{2}\right)$ values were found to be less than $200 \mathrm{~cm}-1$ which indicates that the carboxylate groups are chelated and bonded to the metal in a bidentate manner. ${ }^{13}$.

\section{Mass spectrometry}

The molecular ion peak in almost all of derivatives was not observed. In the triorganotin (IV) derivatives 6 and 7 the major fragmentation observed is due to loss of the ligand moiety from the tin derivatives (Scheme 2; see Experimental). ${ }^{10}$ Successive fragmentation is observed by the loss of " $\mathrm{R}$ " groups $(\mathrm{Me}, \mathrm{Bu}, \mathrm{Ph})$ until the $\mathrm{Sn}^{+}$ion is obtained. In the alternative route " $\mathrm{R}$ " groups are eliminated first and in the next step a molecule of $\mathrm{CO}_{2}$ is evolved from the ligand moiety attached to the tin atom. In the successive steps the remaining substituents are lost from the tin atom.

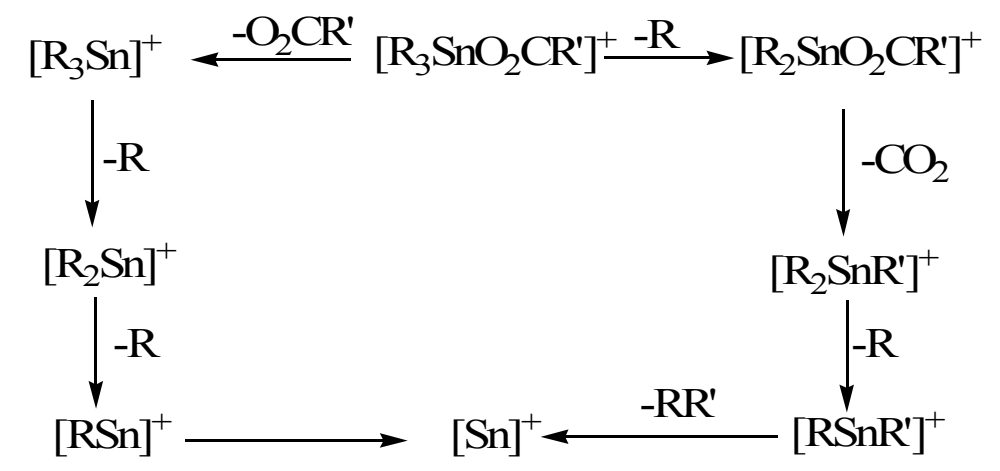

Scheme 2. General mass fragmentation pattern for triorganotin(IV) carboxylates.

In the diorganotin (IV) derivatives fragmentation takes place according to the fragmentation pattern suggested in Scheme 3 (see Experimental). ${ }^{10}$ The main fragmentation observed is due to 
the loss of a ligand molecule followed by the loss of $\mathrm{CO}_{2}$ from the second ligand. The successive loss of " $\mathrm{R}$ " groups and the loss of the remaining part of the ligand proceed until $\mathrm{Sn}^{+}$is obtained. An alternative route suggests that a loss of an " $R$ " group occurs first followed by the successive loss of two molecules of $\mathrm{CO}_{2}$ and then the remaining " $\mathrm{R}$ " groups. The third route proposed is the loss of a $\mathrm{CO}_{2}$ molecule followed by the elimination of one ligand and then loss of the " $\mathrm{R}$ " groups.

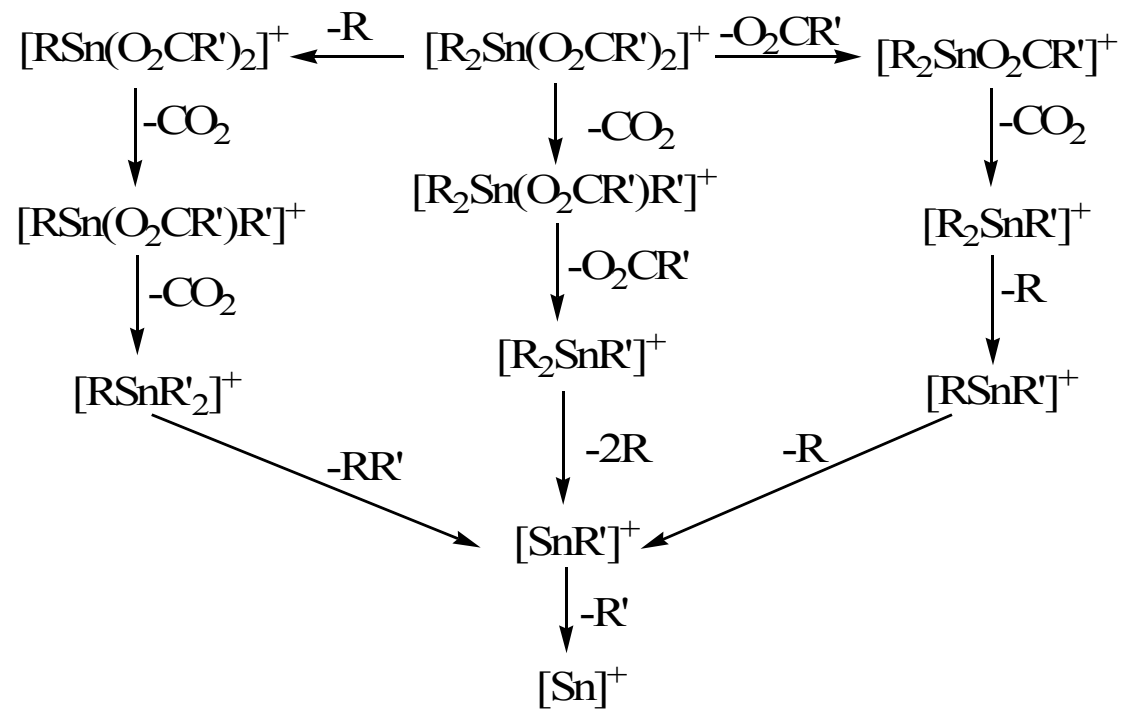

Scheme 3. General Mass fragmentation pattern for diorganotin(IV) carboxylates.

\section{${ }^{1}$ H-NMR Spectroscopy}

Chemical shifts for the various protons in the compounds are given in Table 2. The conclusions drawn from the ${ }^{1} \mathrm{H}-\mathrm{NMR}$ spectral studies lend further support to the mode of bonding discussed above. For instance, absence of signals between 10.00 and $13.00 \mathrm{ppm}$ due to $\mathrm{COOH}$ protons confirms the deprotonation of the carboxylic acid oxygen atom of the ligand upon complexation. Most interestingly the geometry of the double bond in the maleate side chain was trans and not cis which would have been expected. Evidence for this assignment is clear from the large coupling constants (ca. $15 \mathrm{~Hz}$ ) in all the ${ }^{1} \mathrm{H}-\mathrm{NMR}$ spectra of the complexes 1-4 (Table 2). The protons of different organic groups viz., butyl, phenyl and methyl attached to the tin nucleus in these compounds appear at the appropriate positions in accordance to the previously reported values. ${ }^{14,15}$ The number of protons of the various groups, calculated from the integration curves and those calculated for the expected molecular formulae are in complete agreement with each other. 
Table 2. ${ }^{1} \mathrm{H}-\mathrm{NMR}$ data $\left(\delta\right.$, ppm) of organotin compounds $(1-7)^{\mathrm{a}, \mathrm{b}}$

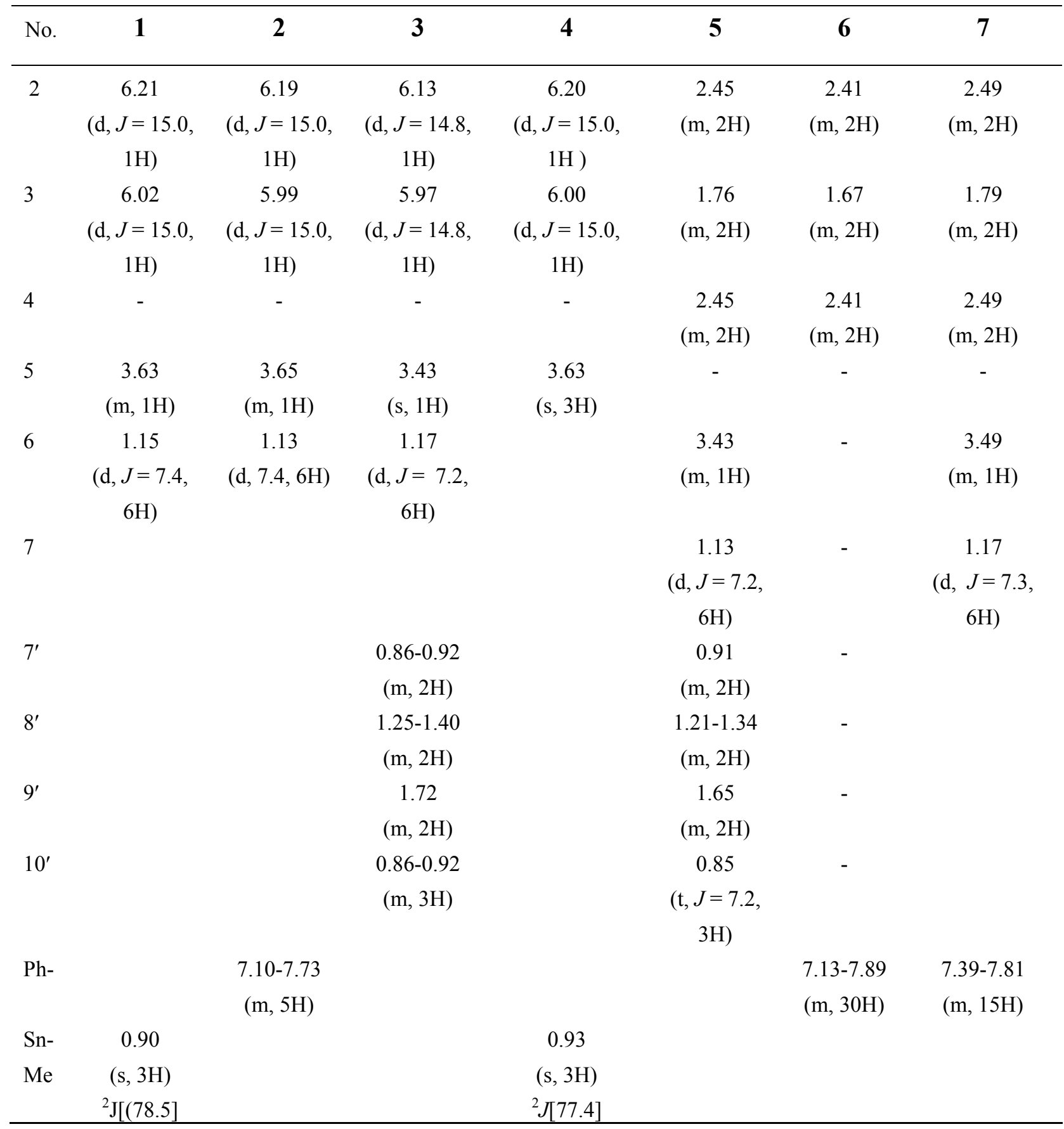

${ }^{\mathrm{a}}$ chemical shift $(\delta)$ in $\mathrm{ppm}^{n} J\left[{ }^{117=119} \mathrm{Sn}, \mathrm{H}\right]$ in $\mathrm{Hz},{ }^{\mathrm{b}}$ multiplicity is given as $\mathrm{s}=$ singlet, $\mathrm{d}=$ doublet, $\mathrm{t}=$ triplet, $\mathrm{m}=$ multiplet.

\section{${ }^{13}$ C-NMR Spectroscopy}

The ${ }^{13} \mathrm{C}$-NMR chemical shifts of various carbon atoms are given in Table 3 . The signals of the carbonyl carbon of the organotin complexes are observed at lower $\delta$ values upon complexation, 
compared to those of the uncomplexed ligands. The ${ }^{13} \mathrm{C}$ chemical shifts of methyl, butyl and phenyl groups attached to tin are observed at similar positions compared with other, analogous compounds. $^{14,15}$

\section{${ }^{119}$ Sn NMR spectra}

${ }^{119} \mathrm{Sn}-\mathrm{NMR}$ chemical shifts of organotin(IV) compounds cover a range of roughly $600 \mathrm{ppm}$. The experimental data (Table 3) shows a significant shift of the resonance peaks to lower frequencies in proceeding from the starting organotin(IV) reagents to the 1:1 and 1:2 adducts, as reported for the analogous organotin(IV) derivatives. ${ }^{16-19}$ These results are in agreement with the hypothesis of an increase in the coordination number of the tin atom in the complexes, and hence, of tin nuclear shielding. ${ }^{16-19}$

Table 3. ${ }^{13} \mathrm{C}-\mathrm{NMR}$ data $(\delta$, ppm) of organotin compounds (1-7)

\begin{tabular}{|c|c|c|c|c|c|c|c|}
\hline No & 1 & 2 & 3 & 4 & 5 & 6 & 7 \\
\hline 1 & $179.4(\mathrm{~s})$ & $173.4(\mathrm{~s})$ & $174.4(\mathrm{~s})$ & $173.7(\mathrm{~s})$ & $177.9(\mathrm{~s})$ & $179.1(\mathrm{~s})$ & $178.9(\mathrm{~s})$ \\
\hline 2 & 134.1 (d) & 128.9 (d) & $131.5(\mathrm{~d})$ & $130.8(d)$ & $38.3(\mathrm{t})$ & $35.7(\mathrm{t})$ & $36.8(\mathrm{t})$ \\
\hline 3 & $131.5(\mathrm{~d})$ & $133.1(\mathrm{~d})$ & 133.7 (d) & $133.2(\mathrm{~d})$ & $28.5(\mathrm{t})$ & $30.1(\mathrm{t})$ & $29.1(\mathrm{t})$ \\
\hline 4 & $164.5(\mathrm{~s})$ & $164.5(\mathrm{~s})$ & $163.9(\mathrm{~s})$ & $163.7(\mathrm{~s})$ & $34.1(\mathrm{t})$ & $35.8(\mathrm{t})$ & $36.7(\mathrm{t})$ \\
\hline 5 & 70.7 (d) & $70.5(\mathrm{~d})$ & 70.1 (d) & $54.1(\mathrm{q})$ & $165.7(\mathrm{~s})$ & $167.7(\mathrm{~s})$ & $168.9(\mathrm{~s})$ \\
\hline 6 & $21.3(q)$ & $21.7(\mathrm{q})$ & $20.7(q)$ & & $70.1(\mathrm{~d})$ & & 71.4 (d) \\
\hline 7 & & & & & $21.7(\mathrm{q})$ & & $20.8(q)$ \\
\hline $\mathrm{Sn}-\mathrm{Me}$ & $9.51(q)$ & & & $9.45(q)$ & & & \\
\hline $7^{\prime}$ & & & $26.6(t)$ & & $26.4(\mathrm{t})$ & & \\
\hline $8^{\prime}$ & & & $30.7(\mathrm{t})$ & & $29.9(\mathrm{t})$ & & \\
\hline $9^{\prime}$ & & & $24.9(\mathrm{t})$ & & $26.8(\mathrm{t})$ & & \\
\hline $10^{\prime}$ & & & $13.5(q)$ & & $13.7(\mathrm{t})$ & & \\
\hline $1^{\prime}$ & & $138.2(\mathrm{~s})$ & & & & $136.1(\mathrm{~s})$ & $137.8(\mathrm{~s})$ \\
\hline $2^{\prime}, 6^{\prime}$ & & $129.9(\mathrm{~d})$ & & & & $129.5(\mathrm{~d})$ & $134.2(\mathrm{~d})$ \\
\hline $3^{\prime}, 5^{\prime}$ & & $129.7(d)$ & & & & $129.1(\mathrm{~d})$ & $133.0(\mathrm{~d})$ \\
\hline $6^{\prime}$ & & $129.8(\mathrm{~d})$ & & & & $129.8(d)$ & $131.7(d)$ \\
\hline $\mathrm{Sn}^{119}$ & -330 & -310.5 & -260 & -320 & -300 & -170 & -150 \\
\hline
\end{tabular}

\section{Biological studies}

Antibacterial activity: Antibacterial activity was evaluated using two Gram positive (Bacillus subtilis, Staphlococcus aureus) and four Gram-negative (Escherichia coli, Schigella flexenari, Pseudomonas aeruginosa, Salmonella typh) bacteria and the results are summarized in Table 4. In order to have a basis of comparison of our results, Imipinem was used as the standard drug. 
From the results in Table 4 it may be concluded that that diorganotin(IV) complexes are slightly less reactive than triorganotin(IV) complexes.

Table 4. Anti bacterial bioassay results ${ }^{\mathrm{a}, \mathrm{b}, \mathrm{c}, \mathrm{d}}$ for $\mathrm{R}_{2} \mathrm{SnL}$ and $\mathrm{R}_{3} \mathrm{SnL}$ (Inhibition zone in $\mathrm{mm}$ )

\begin{tabular}{lcccccccc}
\hline Micro-organism & $\mathbf{1}$ & $\mathbf{2}$ & $\mathbf{3}$ & $\mathbf{4}$ & $\mathbf{5}$ & $\mathbf{6}$ & $\mathbf{7}$ & $\begin{array}{c}\text { Standard } \\
\text { drug }\end{array}$ \\
\hline Gram Positive & & & & & & & & \\
Bacillus subtills & 18 & 17 & 13 & 14 & 16 & 25 & 24 & 31 \\
Staphlococcus aureus & na & 14 & 12 & 12 & 16 & 24 & 20 & 43 \\
Gram Negative & & & & & & & & \\
Escherichia coli & 18 & na & na & 18 & 18 & 25 & na & 30 \\
Schigella flexenari & na & 13 & 18 & na & na & 22 & na & 33 \\
Pseudomonas aeruginosa & 14 & 14 & 20 & 14 & na & 20 & 18 & 25 \\
Salmonella typh & 18 & 20 & 14 & 18 & 17 & 22 & 20 & 41 \\
\hline
\end{tabular}

${ }^{\mathrm{a}}$ Concentration used: $1.00 \mathrm{mg} / 1.00 \mathrm{~mL}$ of DMSO; ${ }^{\mathrm{b}}$ size of well: $6 \mathrm{~mm}$ (diameter); ${ }^{\mathrm{c}}$ Standard drug: Imipinem; ${ }^{\mathrm{d}}$ na: no activity.

\section{Experimental Section}

General Procedures. All chemical and instrumental analyses were performed at the International Center for Chemical Sciences, H.E.J. Research Institute of Chemistry, University of Karachi, Pakistan. All melting points were uncorrected and recorded in glass capillary tubes using a Büchi 535 melting point apparatus. The UV spectra were recorded on a Shimadzu UV240 (Shimadzu Corporation Tokyo, Japan) spectrophotometer. The IR spectra were recorded on a Jasco IRA-1 (Japan Spectroscopic Co. Ltd., Tokyo, Japan) and a Shimadzu IR-460 (Shimadzu Corporation, Tokyo, Japan) instrument. The ${ }^{1} \mathrm{H}-\mathrm{NMR}$ spectra were scanned on a Bruker AM 400 FT NMR a spectrometers using TMS as an internal standard. The ${ }^{13} \mathrm{C}$-NMR spectra were recorded at $100 \mathrm{MHz}$. The mass spectra were scanned on either a Varian-MAT $112 \mathrm{~S}$ or a Finnigan MAT-112 and 312A double focusing mass spectrometer connected to DEC PDP 11/34 and IBM-AT compatible PC based system, respectively.

Synthesis of ligands. A ten fold excess of the dry alcohols viz., methanol, isopropanol and triphenylmethanol were separately added to maleic anhydride and glutaric anhydride and the subsequent mixtures were heated under reflux for 3 hours with constant stirring. Each reaction mixture was then evaporated under reduced pressure to remove the excess of the respective alcohol and the product half esters were dried in a desicator under reduced pressure. 


\section{Synthesis of complexes}

(a) The general method for the synthesis of diorganotin(IV) derivatives

Five new diorganotin(IV) compounds 1-5 were prepared as follows: For compounds 1, 2 and 4; to a chloroform solution ( $50 \mathrm{ml}$ ) of the ligands ( $0.01 \mathrm{~mol})$ were added the diorganotin chloride $(0.005 \mathrm{~mol})$ and $\mathrm{Et}_{3} \mathrm{~N}(0.01 \mathrm{~mol})$. The resultant mixture was heated under reflux with stirring for 3 hours and then allowed to stand at $25^{\circ} \mathrm{C}$ for 10 hours. The precipitated $\mathrm{Et}_{3} \mathrm{NH}_{4} \mathrm{Cl}$ salt that formed was filtered and the filtrate was evaporated under vacuum to yield a solid residue which was recrystalized from dichloromethane/hexane (1:1). For the synthesis of the two diorganotin(IV) compounds $\mathbf{3}$ and $\mathbf{5}$, the procedure was modified and involved a reflux period of 6 hours and the use of toluene as solvent and using a "Dean and Stark" apparatus.

\section{(b) The general method for the synthesis of triorganotin(IV) derivatives}

Two new triorganotin(IV) compounds i.e. triphenyltin(IV) triphenylmethyl glutrate (6) and triphenyltin(IV) monoisopropyl glutrate (7) were prepared as follows: To a solution of the carboxylate ligands $(\mathrm{HL})(0.01 \mathrm{~mol})$ in chloroform $(50 \mathrm{ml})$ was added $\operatorname{dry} \mathrm{Et}_{3} \mathrm{~N}(0.1 \mathrm{~mol})$ followed by the addition of the triorganotin chloride $(0.01 \mathrm{~mol})$ in solid form at $25^{\circ} \mathrm{C}$ and the resulting mixture was heated under refux for $3 \mathrm{~h}$. After cooling the reaction mixture to $25^{\circ} \mathrm{C}$ the precipitated $\mathrm{Et}_{3} \mathrm{NHCl}$ was filtered off and the solvent was removed from the filtrate by a rotary evaporation. The solid residue was triturated with ethanol to afford the pure products.

Dimethyltin(IV) bis monoisopropyl maleate (1). Solid; Yield: $84 \%$; mp $71{ }^{\circ} \mathrm{C}$; $\mathrm{MS}$ ( $\mathrm{m} / \mathrm{z}$, rel. int. $) \quad 449 \quad\left(14 \%, \quad\left[\left(\mathrm{CH}_{3}\right)_{2} \mathrm{CHCO}_{2} \mathrm{CH}=\mathrm{CHCO}_{2}\right]_{2} \mathrm{SnCH}_{3}{ }^{+}\right), \quad 434 \quad(11 \%$, $\left.\left[\left(\mathrm{CH}_{3}\right)_{2} \mathrm{CHCO}_{2} \mathrm{CH}=\mathrm{CHCO}_{2}\right]_{2} \mathrm{Sn}^{+}\right), \quad 307 \quad\left(12 \%, \quad\left[\left(\mathrm{CH}_{3}\right)_{2} \mathrm{CHCO}_{2} \mathrm{CH}=\mathrm{CHCO}_{2}\right] \mathrm{Sn}\left(\mathrm{CH}_{3}\right)_{2}{ }^{+}\right), \quad 277$ $\left(59 \%, \quad\left[\left(\mathrm{CH}_{3}\right)_{2} \mathrm{CHCO}_{2} \mathrm{CH}=\mathrm{CHCO}_{2}\right] \mathrm{Sn}^{+}\right), 249 \quad\left(5 \%, \quad\left[\left(\mathrm{CH}_{3}\right)_{2} \mathrm{CHCO}_{2} \mathrm{CH}=\mathrm{CH}\right] \mathrm{SnCH}_{3} \mathrm{H}^{+}\right), 233$ $\left(26 \%, \quad\left[\left(\mathrm{CH}_{3}\right)_{2} \mathrm{CHCO}_{2} \mathrm{CH}=\mathrm{CH}\right] \mathrm{Sn}^{+}\right), 157 \quad\left(78 \%, \quad\left[\left(\mathrm{CH}_{3}\right)_{2} \mathrm{CHCO}_{2} \mathrm{CH}=\mathrm{CHCO}_{2}\right]^{+}\right), \quad 113 \quad(29 \%$, $\left.\left[\left(\mathrm{CH}_{3}\right)_{2} \mathrm{CHCOOCH}=\mathrm{CH}\right]^{+}\right)$; Anal. Calcd. for $\mathrm{C}_{16} \mathrm{H}_{24} \mathrm{O}_{8} \mathrm{Sn}$ (464): C, 41.38; H, 5.17. Found: C, 41.35; H, 5.09.

Diphenyltin(IV) bis monoisopropyl maleate (2). Solid; Yield: $83 \%$; mp $65-67{ }^{\circ} \mathrm{C}$; $\mathrm{MS}(\mathrm{m} / \mathrm{z}$, rel. int.): $511 \quad\left(15 \%, \quad\left[\left(\mathrm{CH}_{3}\right)_{2} \mathrm{CHCO}_{2} \mathrm{CH}=\mathrm{CHCO}_{2}\right]_{2} \mathrm{SnC}_{6} \mathrm{H}_{5}{ }^{+}\right), \quad 434 \quad(12 \%$, $\left.\left[\left(\mathrm{CH}_{3}\right)_{2} \mathrm{CHCO}_{2} \mathrm{CH}=\mathrm{CHCO}_{2}\right]_{2} \mathrm{Sn}^{+}\right), 431 \quad\left(14 \%, \quad\left[\left(\mathrm{CH}_{3}\right)_{2} \mathrm{CHCO}_{2} \mathrm{CH}=\mathrm{CHCO}_{2}\right] \mathrm{Sn}\left(\mathrm{C}_{6} \mathrm{H}_{5}\right)_{2}{ }^{+}\right), \quad 311$ $\left(12 \%,\left[\left(\mathrm{CH}_{3}\right)_{2} \mathrm{CHCO}_{2} \mathrm{CH}=\mathrm{CH}\right] \mathrm{SnC}_{6} \mathrm{H}_{5} \mathrm{H}^{+}\right), 277 \quad\left(61 \%,\left[\left(\mathrm{CH}_{3}\right)_{2} \mathrm{CHCO}_{2} \mathrm{CH}=\mathrm{CHCO}_{2}\right] \mathrm{Sn}^{+}\right), 233$ (28, $\left.\left[\left(\mathrm{CH}_{3}\right)_{2} \mathrm{CHCO}_{2} \mathrm{CH}=\mathrm{CH}\right] \mathrm{Sn}^{+}\right), \quad 157 \quad\left(65 \%, \quad\left[\left(\mathrm{CH}_{3}\right)_{2} \mathrm{CHCO}_{2} \mathrm{CH}=\mathrm{CHCO}_{2}\right]^{+}\right), \quad 113 \quad(31 \%$, $\left.\left[\left(\mathrm{CH}_{3}\right)_{2} \mathrm{CHCOOCH}=\mathrm{CH}\right]^{+}\right)$; Anal. Calcd. for $\mathrm{C}_{26} \mathrm{H}_{28} \mathrm{O}_{8} \mathrm{Sn}$ (588): C, 53.06; H, 4.76. Found: C, $53.01 ; \mathrm{H}, 4.81$.

Dibutyltin(IV) bis monoispropyl maleate (3). Solid; Yield: $80 \%$; mp $79{ }^{\circ} \mathrm{C}$; $\mathrm{MS}(\mathrm{m} / \mathrm{z}$, rel. int.): $\quad 491 \quad\left(17 \%, \quad\left[\left(\mathrm{CH}_{3}\right)_{2} \mathrm{CHCO}_{2} \mathrm{CH}=\mathrm{CHCO}_{2}\right]_{2} \mathrm{SnC}_{4} \mathrm{H}_{9}{ }^{+}\right), \quad 434 \quad(12 \%$, $\left.\left[\left(\mathrm{CH}_{3}\right)_{2} \mathrm{CHCO}_{2} \mathrm{CH}=\mathrm{CHCO}_{2}\right]_{2} \mathrm{Sn}^{+}\right), 391 \quad\left(19 \%, \quad\left[\left(\mathrm{CH}_{3}\right)_{2} \mathrm{CHCO}_{2} \mathrm{CH}_{2} \mathrm{CHCO}_{2}\right] \mathrm{Sn}\left(\mathrm{C}_{4} \mathrm{H}_{9}\right)_{2}{ }^{+}\right), 291$ $\left(9 \%, \quad\left[\left(\mathrm{CH}_{3}\right)_{2} \mathrm{CHCO}_{2} \mathrm{CH}=\mathrm{CH}\right] \mathrm{SnC}_{4} \mathrm{H}_{9} \mathrm{H}^{+}\right), 277 \quad\left(31 \%, \quad\left[\left(\mathrm{CH}_{3}\right)_{2} \mathrm{CHCO}_{2} \mathrm{CH}=\mathrm{CHCO}_{2}\right] \mathrm{Sn}^{+}\right), 233$ $\left(35 \%, \quad\left[\left(\mathrm{CH}_{3}\right)_{2} \mathrm{CHCO}_{2} \mathrm{CH}=\mathrm{CH}\right] \mathrm{Sn}^{+}\right), 157 \quad\left(57 \%, \quad\left[\left(\mathrm{CH}_{3}\right)_{2} \mathrm{CHCO}_{2} \mathrm{CH}=\mathrm{CHCO}_{2}\right]^{+}\right), \quad 113 \quad(28 \%$, $\left.\left[\left(\mathrm{CH}_{3}\right)_{2} \mathrm{CHCO}_{2} \mathrm{CH}=\mathrm{CH}\right]^{+}\right)$; Anal. Calcd. for $\mathrm{C}_{22} \mathrm{H}_{36} \mathrm{O}_{8} \mathrm{Sn}$ (548): C, 48.18; H, 6.57. Found: $\mathrm{C}$, 48.09; H, 6.66. 
Dimethyltin(IV) bis monomethyl maleate (4). Solid; Yield: $85 \%$; mp $75{ }^{\circ} \mathrm{C}$; $\mathrm{MS}(\mathrm{m} / z$, rel. int.): $393\left(18 \%,\left[\mathrm{CH}_{3} \mathrm{CO}_{2} \mathrm{CH}=\mathrm{CHCO}_{2}\right]_{2} \mathrm{SnCH}_{3}{ }^{+}\right), 378\left(19 \%,\left[\mathrm{CH}_{3} \mathrm{CO}_{2} \mathrm{CH}=\mathrm{CHCO}_{2}\right]_{2} \mathrm{Sn}^{+}\right), 279$ $\left(21 \%,\left[\mathrm{CH}_{3} \mathrm{CO}_{2} \mathrm{CH}=\mathrm{CHCO}_{2}\right] \mathrm{Sn}\left(\mathrm{CH}_{3}\right)_{2}{ }^{+}\right), 249\left(35 \%, \quad\left[\mathrm{CH}_{3} \mathrm{CO}_{2} \mathrm{CH}=\mathrm{CHCO}_{2}\right] \mathrm{Sn}^{+}\right), 221 \quad(25 \%$, $\left.\left[\mathrm{CH}_{3} \mathrm{CO}_{2} \mathrm{CH}=\mathrm{CH}\right] \mathrm{SnCH}_{3} \mathrm{H}^{+}\right), \quad 205 \quad\left(31 \%, \quad\left[\mathrm{CH}_{3} \mathrm{CO}_{2} \mathrm{CH}=\mathrm{CH}\right] \mathrm{Sn}^{+}\right), \quad 129 \quad(49 \%$, $\left.\left[\mathrm{CH}_{3} \mathrm{CO}_{2} \mathrm{CH}=\mathrm{CHCO}_{2}\right]^{+}\right), 85\left(27 \%,\left[\mathrm{CH}_{3} \mathrm{CO}_{2} \mathrm{CH}=\mathrm{CH}\right]^{+}\right)$; Anal. Calcd. for $\mathrm{C}_{12} \mathrm{H}_{16} \mathrm{O}_{8} \mathrm{Sn}$ (408): $\mathrm{C}$, 35.29; H, 3.92. Found: C, 35.07; H, 3.99.

Dibutyltin(IV) bis monoispropyl gulatrate (5). Solid; Yield: $79 \%$; mp $85{ }^{\circ} \mathrm{C}$; $\mathrm{MS}(\mathrm{m} / \mathrm{z}$, rel. int.): $523\left(14 \%, \quad\left[\left(\mathrm{CH}_{3}\right)_{2} \mathrm{CHCO}_{2}\left(\mathrm{CH}_{2}\right)_{3} \mathrm{CO}_{2}\right]_{2} \mathrm{SnC}_{4} \mathrm{H}_{9}{ }^{+}\right), 479 \quad\left(5 \%, \quad\left[\left(\mathrm{CH}_{3}\right)_{2} \mathrm{CHCO}_{2}\left(\mathrm{CH}_{2}\right)_{3}\right]_{2}\right.$ $\left.\mathrm{SnC}_{4} \mathrm{H}_{9}{ }^{+}\right), \quad 466 \quad\left(10 \%, \quad\left[\left(\mathrm{CH}_{3}\right)_{2} \mathrm{CHCO}_{2}\left(\mathrm{CH}_{2}\right)_{3} \mathrm{CO}_{2}\right]_{2} \mathrm{Sn}^{+}\right), \quad 407 \quad(17 \%$, $\left.\left[\left(\mathrm{CH}_{3}\right)_{2} \mathrm{CHCO}_{2}\left(\mathrm{CH}_{2}\right)_{3} \mathrm{CO}_{2}\right] \mathrm{SnC}_{4} \mathrm{H}_{9}{ }^{+}\right), 293 \quad\left(59 \%, \quad\left[\left(\mathrm{CH}_{3}\right)_{2} \mathrm{CHCO}_{2}\left(\mathrm{CH}_{2}\right)_{3} \mathrm{CO}_{2}\right] \mathrm{Sn}^{+}\right), 173 \quad(35 \%$, $\left.\left[\left(\mathrm{CH}_{3}\right)_{2} \mathrm{CHCO}_{2}\left(\mathrm{CH}_{2}\right)_{3} \mathrm{CO}_{2}\right]^{+}\right), 129\left(41 \%,\left[\left(\mathrm{CH}_{3}\right)_{2} \mathrm{CHCO}_{2}\left(\mathrm{CH}_{2}\right)_{3}\right]^{+}\right)$; Anal. Calcd. for $\mathrm{C}_{24} \mathrm{H}_{44} \mathrm{O}_{8} \mathrm{Sn}$ (580): C, 49.66; H, 7.59. Found: C, 49.42; H, 7.28.

Triphenyltin(IV) triphenylmethyl glutrate (6). Solid; Yield: $84 \%$; mp 88-89 ${ }^{\circ} \mathrm{C}$; $\mathrm{MS}(\mathrm{m} / z$, rel. int.): $647\left(6 \%, \quad\left[\left(\mathrm{C}_{6} \mathrm{H}_{5}\right)_{3} \mathrm{CCO}_{2}\left(\mathrm{CH}_{2}\right)_{3} \mathrm{CO}_{2}\right] \mathrm{Sn}\left(\mathrm{C}_{6} \mathrm{H}_{5}\right)_{2}{ }^{+}\right), \quad 603 \quad\left(28 \%, \quad\left[\left(\mathrm{C}_{6} \mathrm{H}_{5}\right)_{3} \mathrm{CCO}_{2}\left(\mathrm{CH}_{2}\right)_{3}\right]\right.$ $\left.\mathrm{Sn}\left(\mathrm{C}_{6} \mathrm{H}_{5}\right)_{2}{ }^{+}\right), \quad 526 \quad\left(17 \%, \quad\left[\left(\mathrm{C}_{6} \mathrm{H}_{5}\right)_{3} \mathrm{CCO}_{2}\left(\mathrm{CH}_{2}\right)_{3}\right] \mathrm{SnC}_{6} \mathrm{H}_{5}{ }^{+}\right), \quad 493 \quad(29 \%$, $\left.\left[\left(\mathrm{C}_{6} \mathrm{H}_{5}\right)_{3} \mathrm{CCO}_{2}\left(\mathrm{CH}_{2}\right)_{3} \mathrm{CO}_{2}\right] \mathrm{Sn}^{+}\right), \quad 449 \quad\left(31 \%, \quad\left[\left(\mathrm{C}_{6} \mathrm{H}_{5}\right)_{3} \mathrm{CCO}_{2}\left(\mathrm{CH}_{2}\right)_{3}\right] \mathrm{Sn}^{+}\right), \quad 373 \quad(35 \%$, $\left.\left[\left(\mathrm{C}_{6} \mathrm{H}_{5}\right)_{3} \mathrm{CCO}_{2}\left(\mathrm{CH}_{2}\right)_{3} \mathrm{CO}_{2}\right]^{+}\right), 329\left(57 \%,\left[\left(\mathrm{C}_{6} \mathrm{H}_{5}\right)_{3} \mathrm{CCO}_{2}\left(\mathrm{CH}_{2}\right)_{3}\right]^{+}\right)$; Anal. Calcd. for $\mathrm{C}_{42} \mathrm{H}_{36} \mathrm{O}_{4} \mathrm{Sn}$ (724): C, 69.61; H, 4.97. Found: C, 69.72; H, 4.81.

Triphenyltin(IV) monoisopropyl glutrate (7). Solid; Yield: $77 \%$; mp 88-89 ${ }^{\circ} \mathrm{C}$; $\mathrm{MS}(\mathrm{m} / \mathrm{z}$, rel. int.): $447 \quad\left(18 \%, \quad\left[\left(\mathrm{CH}_{3}\right)_{2} \mathrm{CHCO}_{2}\left(\mathrm{CH}_{2}\right)_{3} \mathrm{CO}_{2}\right] \mathrm{Sn}\left(\mathrm{C}_{6} \mathrm{H}_{5}\right)_{2}{ }^{+}\right), \quad 403 \quad(27 \%$, $\left.\left[\left(\mathrm{CH}_{3}\right)_{2} \mathrm{CHCO}_{2}\left(\mathrm{CH}_{2}\right)_{3}\right] \mathrm{Sn}\left(\mathrm{C}_{6} \mathrm{H}_{5}\right)_{2}{ }^{+}\right), 326\left(13 \%, \quad\left[\left(\mathrm{CH}_{3}\right)_{2} \mathrm{CHCO}_{2}\left(\mathrm{CH}_{2}\right)_{3}\right] \mathrm{Sn}\left(\mathrm{C}_{6} \mathrm{H}_{5}\right)^{+}\right), 293 \quad(61 \%$, $\left.\left[\left(\mathrm{CH}_{3}\right)_{2} \mathrm{CHCO}_{2}\left(\mathrm{CH}_{2}\right)_{3} \mathrm{CO}_{2}\right] \mathrm{Sn}^{+}\right), \quad 249 \quad\left(26 \%, \quad\left[\left(\mathrm{CH}_{3}\right)_{2} \mathrm{CHCO}_{2}\left(\mathrm{CH}_{2}\right)_{3}\right] \mathrm{Sn}^{+}\right), \quad 173 \quad(31 \%$, $\left.\left[\left(\mathrm{CH}_{3}\right)_{2} \mathrm{CHCO}_{2}\left(\mathrm{CH}_{2}\right)_{3} \mathrm{CO}_{2}\right]^{+}\right), 129\left(49 \%,\left[\left(\mathrm{CH}_{3}\right)_{2} \mathrm{CHCO}_{2}\left(\mathrm{CH}_{2}\right)_{3}\right]^{+}\right)$; Anal. Calcd. for $\mathrm{C}_{26} \mathrm{H}_{28} \mathrm{O}_{4} \mathrm{Sn}$ (524): C, 59.54; H, 5.34. Found: C, 59.49; H, 5.17.

\section{Antibacterial activity}

The antibacterial activity was determined by using the agar well diffusion method. ${ }^{20}$ The wells were dug in the media with a sterile borer and an eight-hour-old bacterial inoculums containing ca. 104-106 colony-forming units (CFU)/mL was spread onto the surface of the nutrient agar using a sterile cotton swab. The recommended concentration of the test sample $(2 \mathrm{mg} / \mathrm{mL}$ in DMSO) was introduced into the respective wells. Other wells containing DMSO and the reference antibacterial drug served as negative and positive controls, respectively. The plates were incubated immediately at $37^{\circ} \mathrm{C}$ for $20 \mathrm{~h}$. The activity was determined by measuring the diameter of the inhibition zone (in $\mathrm{mm}$ ) showing complete inhibition. Growth inhibition was calculated with reference to the positive control. 


\section{References and Notes}

1. Gielen, M. Main Group Met. Chem. 1994, 17, 1.

2. Ng S.W.; Kuthubutheen, A. J.; Arifin, Z.; Wei, C.; Das, V. G. K.; Schulze, B. K. C.; Molloy, Y. W. H.; Mak, T. C. W. J. Organomet. Chem. 1991, 403, 101.

3. Van der Kerk G. J. M., "Organotin Compounds", Conf. Tin Consumption, [Pap.] 181 (1972); Chem. Abstr. 1975, 83, 10204x

4. Narayanan, V. L.; Nasr, M.; Paul, K. D.; In Tin-Based Antitumor Drugs Gielen, M. Ed.; Springer- Verlag: Berlin, 1990; pp 201-17.

5. William, R.; Biesemans M.; Boualam, M.; Delmotto, A.; El Khloufi, A.; Gielen, M. Appl. Organomet. Chem. 1993, 7, 311.

6. Blunden, S. J.; Crowe, A. J.; Monk, A. W. Appl. Organomet. Chem. 1987, 1, 57.

7. Cusak, P. A.; Hobbs, L. A.; Smith, P. J.; Brooks, J. S. J. Text. Inst. 1980, 71, 138.

8. Kumari, A.; Singh, I.; Tandon, J. P. Appl. Organomet. Chem. 1995, 9, 127.

9. Gielen, M.; Baulam, M.; Mahieu, B.; Tiekink, E. R. T. Appl. Organomet. Chem. 1994, 8, 9.

10. Ahmad, F.; Pervez, M., Ali, S.; Mazher, M.; Munir, A. Synth. React. Inorg. Met.-Org. Chem. 2002, 32, 665 .

11. Li, J.; Zhao, G.; Xiong, G.; Ma, Y. Synth. React. Inorg. Met.-Org. Chem. 2001, 31, 85.

12. Nath, M.; Yadav, R. Bull. Chem. Soc. Jpn. 1998, 71, 1355.

13. Sandhu, J. K.; Gupta, R.; Sandhu, S. S.; Parish, R. V. Polyhedron 1985, 4, 81.

14. Nath, M.; Goyal, S.; Eng, G.; Ogawura, N. Synth. React. Inorg. Met.-Org. Chem. 1998, 28, 1619.

15. Shahida, K.; Ali, S.; Shahzadi, S.; Badshah, A.; Khan, K. M.; Maharvi, G. M., Synth. React. Inorg. Met.-Org. Chem., 2003, 33, 1223.

16. Wrackmeyer, B.; Ali, S.; Storch, W.; Vosteen, M.; Z.Naturforsch. 1999, 54b, 1165.

17. Wrackmeyer, B. Chem. Br. 1990, 48.

18. Eng, G.; Song, X.; Duong, Q.; Strickman, D.; Glass, J.; May, L. Appl. Organomet. Chem. 2003, 17,218.

19. Nath, M.; Pokharia, S.; Eng, G.; Song, X. J. Organometal. Chem. 2003, 669, 109.

20. Rahman, A.; Choudhary, M. I.; Thomsen, W. J.; Bioassay Techniques for Drug Development, Harwood Academic Publishers: The Netherlands, 2001; p 16. 